\title{
O Tema de Pesquisa \\ como mobilizador da ação pedagógica: \\ um relato de experiência sobre o corpo humano
}

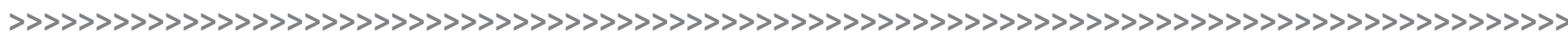

\author{
Denise Bortoletto* \\ Mariane de Araújo Soares Souza** \\ Werllesson de Medeiros***
}

\section{Resumo:}

Este artigo trata de um relato de experiência vivenciada com alunos do 20 ano do Ensino Fundamental do NEI-CAp/UFRN. Tendo o Corpo Humano como nosso Tema de Pesquisa, as perguntas iniciais e os saberes prévios das crianças, nortearam a sistematização para o estudo que ocorreu ao longo do ano letivo de 2019. Uma rede temática foi organizada e uma sequência didática pensada para cada etapa do nosso trabalho. Produzimos textos individuais e coletivos, desenhos e ilustrações, painéis, linhas do tempo, pesquisas em textos informativos, aulas no laboratório de Ciências, visitas de campo em museus. Para as crianças, estudar o corpo humano possibilitou a realização do desejo de investigação desta temática favorecendo o desenvolvimento de cada uma delas.

\section{Palavras-chave:}

Tema de Pesquisa. Corpo Humano. Anos Iniciais do Ensino Fundamental.

\section{Abstract:}

This article deals with an experience report with students of the 2nd year of Elementary School at NEI-CAp/UFRN. Having the Human Body as our Research Theme, the initial questions and the previous knowledge of the children, guided the systematization for the study that took place during the 2019 school year. A thematic network was organized and a didactic sequence designed for each stage of the study. We produce individual and collective texts, drawings and illustrations, panels, timelines, informative text research, science lab classes, museum field trips. For the children, studying the human body made possible the desire to investigate this theme favoring the development of each one of them.

\section{Keywords:}

Research Theme. Human Body. Early Years of Elementary School.

\section{Introdução}

Este relato tem como intenção apresentar o Tema de Pesquisa como um recurso metodológico para o trabalho nos Anos Iniciais do Ensino Fundamental. Parte-se da experiência realizada com crianças do $2^{\circ}$ ano do Ensino Fundamental em torno do tema "Corpo Humano". Estudar o corpo humano é desafiador e ao mesmo tempo movimenta as crianças. Elas, ao longo do seu processo de desenvolvimento, observam tacitamente as modificações que ocorrem nessa evolução. Ao início do ano letivo notamos que as curiosidades sobre o corpo humano estavam latentes no grupo em que trabalhamos em

\begin{abstract}
* > Docente no Núcleo de Educação da Infância, Colégio de Aplicação da Universidade Federal do Rio Grande do Norte (NEI-Cap/UFRN). Doutoranda do Programa de Pós-Graduação em Educação da Universidade Federal do Rio Grande do Norte (UFRN). Mestra em Educação pela Universidade Estadual de Campinas (UNICAMP). Pedagoga pela Universidade Federal de Uberlândia (UFU). E-mail: debortoletto@yahoo.com.br.
\end{abstract}

\footnotetext{
** > Mestra em Educação pela Universidade Federal do Rio Grande do Norte (UFRN) e pedagoga pela mesma instituição. Foi professora substituta do Núcleo de Educação da Infância (NEI-CAp/UFRN) entre 2018 e 2019. Atualmente é professora da rede privada de ensino. E-mail: maryannydearaujo@hotmail.com

*** > Aluno do curso de graduação do curso de Ciências Biológicas (Licenciatura) da Universidade Federal do Rio Grande do Norte (UFRN). Desempenha a função de bolsista de apoio técnico no Núcleo de Educação da Infância da UFRN desde o ano de 2017. E-mail: werllessonmedeiros @gmail.com.
} 
2019. Constituído por 21 crianças, 2 professores e 3 bolsistas, as dúvidas e curiosidades dos alunos e professores sobre esta temática viabilizaram o nosso fazer pedagógico.

O estudo foi realizado no Núcleo de Educação da Infância, Colégio de Aplicação da Universidade Federal do Rio Grande no Norte. Para nós, a escola se constitui como o lugar de constituição do saber por meio de um processo construtivo e vivencial. A metodologia adotada nesta instituição é o Tema de Pesquisa, que vem sendo utilizada, conforme nos assinala Rêgo (1999), desde a década de 1980, ocasião da reestruturação curricular da escola.

Segundo a autora, o tema de pesquisa propõe observar três critérios básicos ao organizar os fazeres pedagógicos: o contexto sociocultural das crianças, as áreas de conteúdo e o nível de desenvolvimento infantil. Observamos o contexto sociocultural das crianças partindo dos seus interesses e inquietações que movimentarão suas aprendizagens. Consideramos as crianças como produtoras de culturas e que trazem consigo saberes prévios, valores, linguagens e pertencentes a um grupo social (PROUT, 2010). As áreas de conteúdo são entendidas como os conhecimentos produzidos e sistematizados ao longo da evolução dos tempos. De maneira interdisciplinar as Linguagens, a Matemática, as Ciências Humanas e da Natureza são convidadas para delinear o estudo. Por fim, no nível de desenvolvimento das crianças são observadas suas características de modo global considerando igualmente importante a cognição, a motricidade e os aspectos e afetivo.

\section{O tema de pesquisa como prática metodológica}

Três momentos pedagógicos organizam a realização de um Tema de Pesquisa: estudo da realidade (ER), organização do conhecimento (OC) e aplicação do conhecimento (AC) (RÊGO, 1999).

O ER é um momento de escuta das crianças a fim de levantar o que elas já sabem, o querem saber e quais são suas hipóteses sobre o tema. O professor atua como mediador e precisa estar atento, observar, ouvir e questionar as crianças, de modo a encorajá-las a relatarem suas expectativas para o estudo, além das perguntas, dúvidas e incertezas sobre a temática a ser estudada.

O segundo momento é a OC. Nesta etapa coletamos informações de diferentes fontes bibliográficas que possam responder aos questionamentos levantados por meio do estudo da realidade. A tarefa do professor está voltada para a organização de atividades, experiências ou estratégias que favoreçam a aprendizagem significativa e possibilitem as crianças avançarem na produção do conhecimento.

A AC é caracterizada pela produção construída ao longo estudo. É o relato, por meio de diferentes linguagens, das aprendizagens vivenciadas e mais significativas para as crianças no grupo, ou individualmente. Também ocorre nesta etapa, a retomada das questões iniciais, dúvidas e inquietações. Além disso, "nesse momento, professoras e crianças contribuem com suas impressões, visões e conhecimentos. A partir dessas sínteses, as crianças poderão estruturar ideias transformadoras sobre o mundo que vivem" (RÊGO, 1999, p. 71).

\section{A pesquisa sobre o corpo humano com alunos do 2 ano do Ensino Fundamental}

A pesquisa com crianças contribui para o conhecimento e a ampliação sobre as culturas infantis (ROCHA, 2008). Ouvir a criança é considerar que ela tem uma presença social ativa, antes silenciada pela visão centrada na ação do adulto (PROUT, 2010). Frente 
a esta realidade, a escolha de um tema de pesquisa constitui-se como uma tarefa complexa, pois incorremos o risco de não traduzir a real intenção investigativa da criança, prevalecendo a visão do professor.

No início de nossas escolhas, nós professores, observamos neste grupo, o quanto a opinião de uma criança influenciava a ideia da outra. Assim, com a intenção de assegurar que cada criança expressasse de fato seu desejo de estudo, realizamos individualmente uma identificação de possíveis temas. Nesta oportunidade, cada uma indicou uma temática e a sua justificativa. Como possibilidades de futuras pesquisas, identificamos: corpo humano (7); super-heróis (5); futebol (2) e com uma (1) indicação em cada tema, animais míticos, pássaros, cinema, Japão, Turma da Mônica, mitologia grega, animais do mar, medicina, moscas e matemática. Na fala das crianças ficou evidente que duas temáticas pareciam movimentá-las mais: Corpo Humano e Super-Heróis.

O momento de tomada de decisão quanto a qual tema estudar contou com uma roda de conversa em que, coletivamente, cada criança fez sua defesa quanto a qual tema queria pesquisar. Incialmente, não houve consenso. Os professores passaram então a mediar vários momentos de conversa sobre cada temática a fim de tentar perceber, quais de fato eram os interesses que moviam as crianças. Ao iniciarmos a conversa sobre o Corpo Humano, observamos o quanto essa temática fomentava discussões e curiosidades no grupo. Resolvemos ir à biblioteca para entrar em contato com alguns materiais bibliográficos, imagens e textos, para que pudéssemos enfim decidir quanto ao tema. Em roda, novamente retomamos as discussões quanto a temática e por fim, escolhemos o Corpo Humano para nossos estudos.

Frente a essa escolha, iniciamos a primeira etapa do tema de pesquisa: o estudo da realidade (ER). Esse é também um momento de extremo cuidado pelos professores, pois com ele coletamos dados que delineiam nosso fazer pedagógico. Num exercício individual, cada criança apresentou o que já sabia, o que queria saber e suas hipóteses. Um exemplo pode ser observado na fala de um menino que disse: "Eu sei que o corpo tem células. Eu quero aprender sobre o DNA. Eu acho que o DNA e as células têm a ver.” Outra criança relatou: "Temos coração. Eu quero saber se ele é bonito por dentro igual nos desenhos. Eu não sei se é." Um garoto disse: "Por que o corpo humano tem esse nome?"

De posse de todas as afirmações, hipóteses e curiosidades das crianças, os professores categorizaram esses dados e organizaram uma possível sequência de temáticas para o estudo. Cada grupo maior de temáticas contou com um subgrupo, conforme o quadro a seguir:

Quadro 1 - Grupos e subgrupos da pesquisa

\begin{tabular}{|c|c|c|}
\hline $\begin{array}{l}\text { GRUPO 1: } \\
\text { O CORPO }\end{array}$ & $\begin{array}{l}\text { GRUPO 2: } \\
\text { CÉLULAS E DNA }\end{array}$ & $\begin{array}{l}\text { GRUPO 3: } \\
\text { SISTEMAS }\end{array}$ \\
\hline $\begin{array}{l}\text { Subgrupos: } \\
\text { - partes do corpo; } \\
\text { - crescimento; } \\
\text { - definição do } \\
\text { termo corpo } \\
\text { humano; } \\
\text { - evolução do } \\
\text { corpo ao longo da } \\
\text { história; e } \\
\text { - funcionamento } \\
\text { do corpo. }\end{array}$ & $\begin{array}{l}\text { Subgrupos: } \\
\text { - como as células são } \\
\text { formadas; } \\
\text { - tipos de células; e } \\
\text { - a estrutura do DNA. }\end{array}$ & $\begin{array}{l}\text { Subgrupos: } \\
\text { - sensorial (visão, audição, tato, paladar, } \\
\text { olfato e percepção); } \\
\text { - cardiovascular (estrutura/anatomia do } \\
\text { coração, funcionamento, sague, veias e } \\
\text { circulação); } \\
\text { - esquelético/muscular (ossos, movimento } \\
\text { do corpo); } \\
\text { - respiratório (anatomia do pulmão e } \\
\text { funcionamento); } \\
\text { - excretor (excreção do nariz e o funciona- } \\
\text { mento do sistema); } \\
\text { - tegumentar (cabelo, pelo no corpo e } \\
\text { envelhecimento da pele); } \\
\text { - digestório (necessidade da alimentação); e } \\
\text { - nervoso (cérebro e os nervos). }\end{array}$ \\
\hline
\end{tabular}

Fonte: Elaborado pelos autores (2019). 
A categorização do estudo da realidade contribui para que as professoras pudessem organizar o quadro programático para o estudo. A sistematização deste quadro favoreceu aos professores a construção da problemática que envolve o que as crianças querem saber e quais as suas hipóteses, as áreas de conhecimento convocadas para responder à problemática, os objetivos do estudo, bem como as estratégias didático-metodológicas a serem empregadas. A título ilustrativo, segue um fragmento do quadro programático construído para essa pesquisa:

Quadro 2 - Fragmento do quadro programático do estudo

\begin{tabular}{|c|c|c|c|}
\hline \multicolumn{4}{|l|}{ GRUPO 1: O CORPO } \\
\hline $\begin{array}{l}\text { Hipóteses } \\
\text { O que sabemos }\end{array}$ & $\begin{array}{l}\text { Áreas do } \\
\text { conhecimento }\end{array}$ & Objetivos & $\begin{array}{l}\text { Estratégias } \\
\text { didático- } \\
\text {-metodológicas }\end{array}$ \\
\hline $\begin{array}{l}\text { 1.4. EVOLUÇÃO } \\
\text { DO CORPO AO } \\
\text { LONGO DA } \\
\text { HISTÓRIA } \\
\text { - Antigamente os } \\
\text { homens pareciam } \\
\text { mais velhos e anda- } \\
\text { vam igual animais. } \\
\text { - Os homens da } \\
\text { caverna andavam } \\
\text { se arrastando e } \\
\text { depois começaram } \\
\text { a andar em pé. Os } \\
\text { homens da caverna } \\
\text { tinham o corpo } \\
\text { menor que o da } \\
\text { gente. } \\
\text { - Os homens da } \\
\text { caverna tinham } \\
\text { corpo igual ao dos } \\
\text { gorilas. } \\
\text { - As pessoas viviam } \\
\text { mais tempo anti- } \\
\text { gamente, mais que } \\
\text { 130 anos. } \\
\text { - O corpo humano } \\
\text { antigamente era } \\
\text { bem peludo. }\end{array}$ & $\begin{array}{l}\text { CIÊNCIAS } \\
\text { - Semelhanças e } \\
\text { diferenças no corpo } \\
\text { humano ao longo da } \\
\text { evolução humana. } \\
\text { HISTÓRIA } \\
\text { - Os estudos que ex- } \\
\text { plicam a evolução do } \\
\text { homem: o criacionista } \\
\text { e a teoria científica. } \\
\text { - Tempo histórico e } \\
\text { tempo cronológico. } \\
\text { GEOGRAFIA } \\
\text { - Lugar do planeta } \\
\text { onde viviam os ho- } \\
\text { mens das cavernas. } \\
\text { MATEMÁTICA } \\
\text { - Contagem dos anos. } \\
\text { - Sistema de numera- } \\
\text { ção decimal: unidade, } \\
\text { dezena, centena e } \\
\text { milhar. } \\
\text { - Conceito de adição. } \\
\text { ARTE } \\
\text { - O corpo represen- } \\
\text { tado nas pinturas } \\
\text { rupestres. }\end{array}$ & $\begin{array}{l}\text { - Conhecer a evolu- } \\
\text { ção do corpo humano } \\
\text { ao longo dos tempos } \\
\text { históricos. } \\
\text { - Ter contato com as } \\
\text { diferentes explicações } \\
\text { sobre a evolução do } \\
\text { homem: o criacio- } \\
\text { nismo e a teoria } \\
\text { científica. } \\
\text { - Desenvolver as } \\
\text { noções de tempo } \\
\text { histórico e tempo } \\
\text { cronológico. } \\
\text { - Conhecer, por } \\
\text { meio de mapas, os lu- } \\
\text { gares onde viviam os } \\
\text { homens das cavernas, } \\
\text { observando mudan- } \\
\text { ças e permanências. } \\
\text { - Trabalhar a ideia } \\
\text { da adição pensando } \\
\text { na sequência dos } \\
\text { anos ao longo da } \\
\text { história. } \\
\text { - Conhecer pinturas } \\
\text { rupestres que repre- } \\
\text { sentaram o corpo } \\
\text { humano. }\end{array}$ & $\begin{array}{l}\text { - Projeção de } \\
\text { vídeos e slides } \\
\text { para apresentar a } \\
\text { evolução do corpo } \\
\text { humano ao longo } \\
\text { da história. } \\
\text { - Leitura e } \\
\text { discussão de } \\
\text { textos sobre a } \\
\text { explicação cria- } \\
\text { cionista e a teoria } \\
\text { evolucionista. } \\
\text { - Uso de mapas } \\
\text { antigos e atuais. } \\
\text { - Textos coleti- } \\
\text { vos e registros } \\
\text { individuais. } \\
\text { - Jogos matemá- } \\
\text { ticos e recursos } \\
\text { concretos, como o } \\
\text { Quadro Valor de } \\
\text { Lugar e o material } \\
\text { dourado. } \\
\text { - Fotografias de } \\
\text { pinturas rupestres. }\end{array}$ \\
\hline
\end{tabular}

Fonte: Acervo dos professores (2019).

A partir do quadro, organizamos a rede temática. Com esse instrumento temos a possiblidade de visualizar de maneira ampla o estudo em sua totalidade. 
Figura 1 - Fragmento do quadro programático do estudo

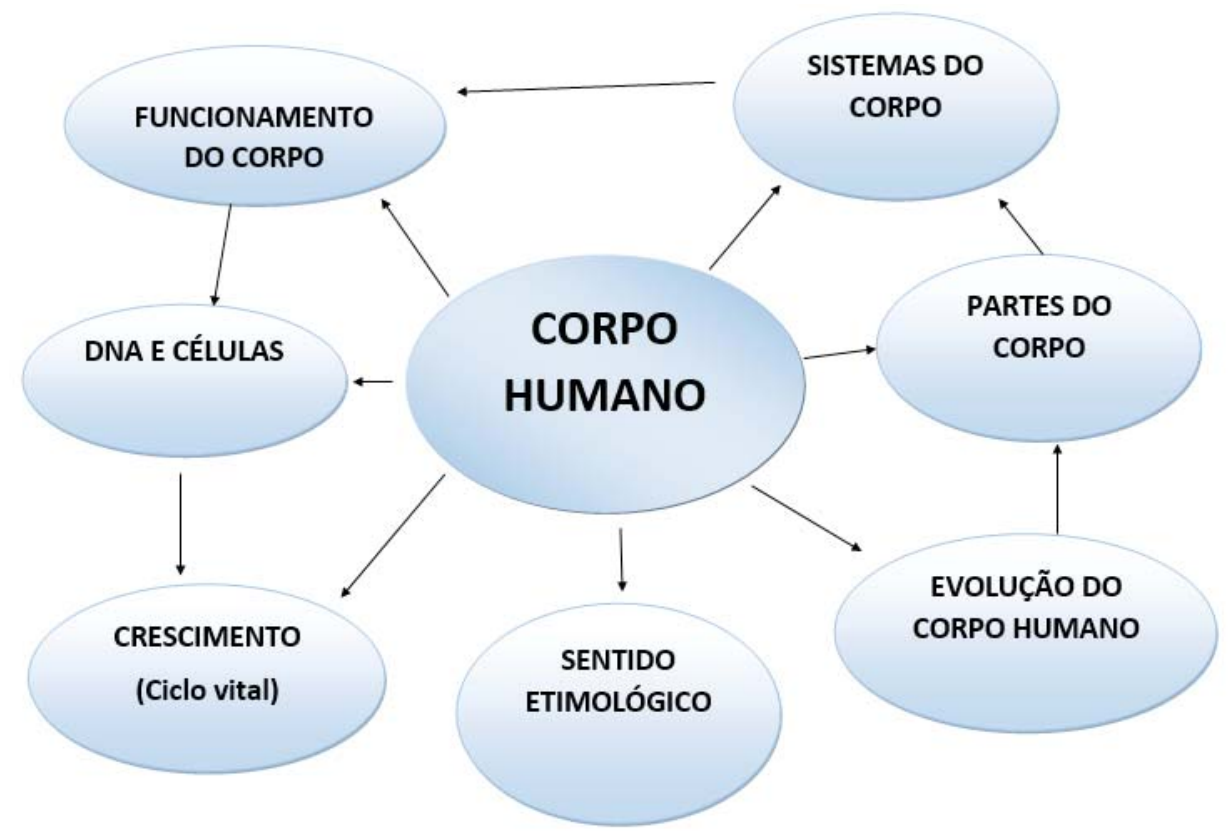

Fonte: Acervo dos professores (2019).

O segundo momento do tema de pesquisa é a organização do conhecimento (OC). Para cada grupo e subgrupo apresentado no Quadro 1, professores e crianças buscaram informações e conhecimentos em diferentes fontes de investigação, como em páginas na internet, livros, revistas científicas, enciclopédias, notícias, dentre outras. De posse dos dados coletados nas pesquisas, os professores, como mediadores nesse processo, organizaram atividades significativas que favoreceram às crianças o avanço em seus saberes, construindo aprendizados novos ou contestando suas ideias iniciais. Contamos também com o apoio de um bolsista do Laboratório de Ciências, onde realizamos aulas teóricas e práticas ao longo de todo o estudo. Nos aspectos teóricos aprofundamos nossos saberes iniciais relacionados as áreas do conhecimento de Ciências e Biologia. Nas atividades práticas, fizemos a medição das alturas das crianças para acompanhar o crescimento ao longo do ano, realizamos observações em microscópio de células vegetais e animais, dissecamos o coração de um boi para compreender como é um coração por dentro, conhecemos protótipos do corpo humano, dentre outras atividades.

Além disso, realizamos visitas técnicas diversas. Fomos ao Museu Câmara Cascudo ${ }^{1}$, localizado em Natal (RN), para conhecer alguns fósseis e aprofundar nossos estudos sobre a evolução humana. Estivemos também no Instituto Internacional de Neurociências Edmond e Lily Safra (IIN-ELS) ${ }^{2}$, em Macaíba (RN), a fim de conhecer os estudos sobre o cérebro que são desenvolvidos lá e aprofundar nossas aprendizagens sobre esta temática. Para ampliar nossos saberes sobre como o corpo é expresso por meio da Arte fomos ao Recife (PE) conhecer o Instituto Ricardo Brennand ${ }^{3}$, onde as crianças puderam, em contato com o acervo, apreciar quadros e esculturas em que o corpo humano está representado.

O último momento do Tema de Pesquisa é a aplicação do conhecimento (AC), entendida como a síntese dos estudos realizados, ou seja, os saberes construídos ao longo da pesquisa. Em função da ampla curiosidade das crianças e da extensão do estudo, optamos pelo registro progressivo das aprendizagens, de modo que durante e após o desenvolvimento de cada subgrupo, documentações foram sendo produzidas, tanto pelos professores quanto pelas crianças. Duas formas de registro foram mais empregadas nesse momento: o desenho e a escrita de textos coletivos. Dois exemplos podem ser observados a seguir:
1 > O Museu Câmara Cascudo é um órgão suplementar da Universidade Federal do Rio Grande no Norte e tem como objetivo viabilizar atividades acadêmicas, educativas, científicas, culturais, artísticas e de lazer. Para maiores informações, consultar: https://www.mccufrn.online. Acesso em: 8 jun. 2019.

$2>$ Informações gerais sobre o Instituto Internacional e seu funcionamento são observadas na página http://www.institutosantosdumont.org.br/unidade/instituto-neurociencias-iinels. Acesso em: 3 set. 2019.

$3>0$ Instituto RB é um espaço cultural composto por um acervo artístico e histórico, que "tem como missão a preservação, a difusão e o acesso à cultura e herança material e imaterial, visando à promoção do capital humano e cultural" (INSTITUTO RICARDO BRENNAND. Sobre. Instituto Ricardo Brennand. Recife: Instituto RB, [c2019?]. Disponível em https://www.institutoricardobrennand. org.br. Acesso em: 28 set. 2019.). 
Quadro 3 - Texto coletivo produzido pelas crianças, com a mediação dos professores, após o estudo sobre as células e o DNA

\section{Título: O que aprendemos sobre as células e o DNA}

Nós estudamos sobre as células do corpo humano e descobrimos que elas são umas das menores partes do corpo. Elas somente podem ser vistas através dos microscópios.

A divisão básica das células é: membrana plasmática, citoplasma e núcleo. Existem células eucariontes, que têm núcleo e as procariontes, que não têm.

Descobrimos que no núcleo das células está o DNA, que é como um código no nosso corpo. Ele dá as nossas características, como: a cor da pele, do cabelo, do olho, decide se é menino ou menina, se o cabelo é cacheado ou liso. O DNA é composto por adenina, citosina, guanina e timina. Seu nome é ácido desoxirribonucleico.

Pesquisamos que o corpo humano possui aproximadamente 130 tipos de células, mas nós estudamos apenas 8 . Foram: cardíaca, neuronal, do intestino delgado, hemácias, epitélio, espermatozoides, ovócito e óssea.

Aprendemos também sobre o nível estrutural biológico do corpo humano. O jeito que ele é organizado é assim: átomos, moléculas, organelas, células, tecidos, órgãos, sistemas e organismos. E agora que já estudamos sobre as células e o DNA, vamos pesquisar sobre os sistemas do corpo humano.

Fonte: Acervo dos professores (2019). 
Figura 2 - Linha do tempo sobre a evolução humana

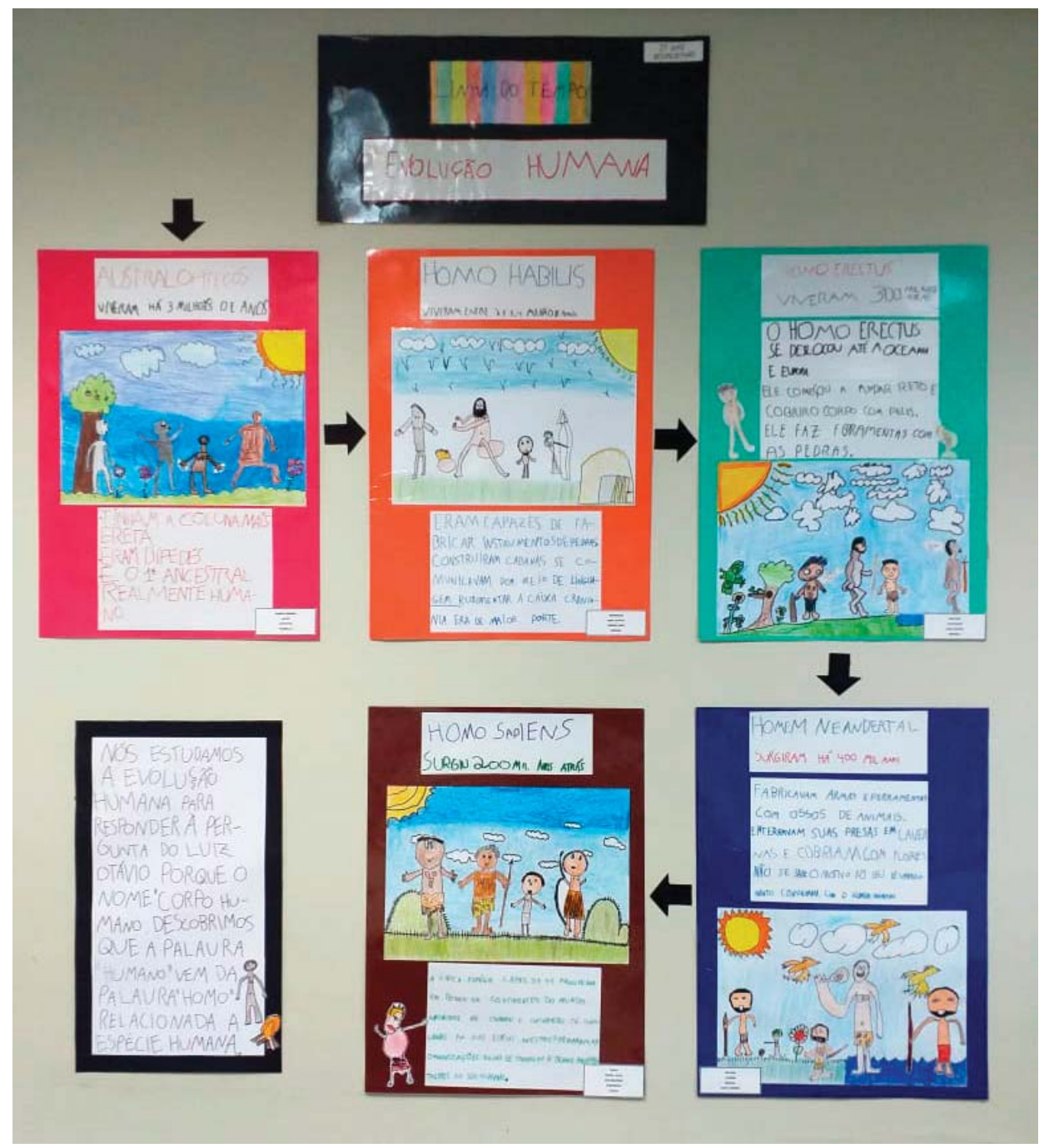

Fonte: Acervo dos professores (2019).

Ao final do ano escolar, apresentaremos à comunidade as produções realizadas ao longo do ano letivo. Também como forma de sistematização dos saberes produzimos um livro ${ }^{4}$ com as produções das crianças contendo textos coletivos e individuais, bem como desenhos sobre o tema de pesquisa "Corpo Humano".

\section{Considerações finais}

A experiência com o trabalho por meio do Tema de Pesquisa proporciona ao professor uma possiblidade pedagógica aproximada ao método científico, de modo a desenvolver com crianças uma cultura elaborada a partir do conhecimento científico (DELIZOICOV; ANGOTTI; PERNAMBUCO, 2002). Por meio desta metodologia de trabalho, o professor precisa se instrumentalizar de recursos e atividades que sejam significativas para as crianças, que tenham como ponto de partida o interesse, a curiosidade, a necessidade e as possibilidades delas, de modo a promover o exercício das múltiplas linguagens e contribuir com o seu desenvolvimento global de maneira efetiva.

Dessa forma, acreditamos que por essa opção metodológica favorecemos a construção do conhecimento, rompendo com a ótica linear e progressiva de currículo. Considerar o

$4>$ Documento em processo de editoração gráfica. 
contexto sociocultural da criança, a estrutura de cada área de conhecimento e os percursos de aprendizagem que o aluno percorre são possíveis caminhos que objetivam esse fim.

Além disso, a ação pedagógica é focada na interdisciplinaridade, pois convida diferentes áreas do conhecimento para responder às dúvidas, curiosidades e inquietações dos alunos. Por interdisciplinaridade compreende-se "o trabalho de integração das diferentes áreas do conhecimento, um real trabalho de cooperação e troca, aberto ao diálogo e ao planejamento" (NOGUEIRA, 2001, p. 27).

A temática Corpo Humano nos favorece a sensação de um estudo voltado exclusivamente para a área das Ciências Biológicas. Entretanto, as curiosidades que moveram os alunos do $2^{\circ}$ ano do Ensino Fundamental foram de natureza interdisciplinar, convidando ao diálogo as Ciências Humanas, as diferentes linguagens e a Matemática. Os saberes sobre o corpo e seu funcionamento, se construíram processualmente e o ensino esteve orientado para além da informação, da descrição de fatos determinados e inquestionáveis levando as crianças à postura ativa, protagonista, desenvolvendo nelas a capacidade de observar, analisar, duvidar, questionar, explicar e intervir no mundo.

Consideramos por fim que a pesquisa sobre o corpo humano proporcionou ao grupo experiências diversas, de modo que as crianças puderam construir novos saberes, bem como contestar os saberes existentes, conduzindo a novas formas de compreensão sobre as Ciências Naturais.

\section{Referências}

DELIZOICOV, Demétrio; ANGOTTI, José André; PERNAMBUCO, Marta Maria. Ensino de Ciências: fundamentos e métodos. São Paulo: Cortez, 2002.

NOGUEIRA, Nilbo. Pedagogia de projetos. São Paulo: Ática, 2001.

PROUT, Alan. Reconsiderando a nova Sociologia da Infância. Cadernos de Pesquisa, São Paulo, V. 40, n. 141, p. 729-750, set./dez. 2010.

RÊGO, Maria Carmem Freire Diógenes. O currículo em movimento. Natal: EDUFRN, 1999. (Caderno Faça e Conte, 2).

ROCHA, Eloisa. Por que ouvir as crianças? Algumas questões para um debate científico multidisciplinar. In: CRUZ, Silvia Helena (org.). A criança fala: a escuta de crianças em pesquisas. São Paulo: Cortez, 2008. p. 43-51. 